\title{
Association of Sex Steroid Priming on Growth Hormone Stimulation Test in Tertiary Care Hospital Settings Rawalpindi
}

\author{
Ain $\mathrm{QU}^{1 *}$, Noreen ${ }^{2}$, Sheikh $\mathrm{WH}^{2}$, Akhtar $\mathrm{H}^{3}$, Asif $\mathrm{N}^{4}, \mathrm{Naz} \mathrm{S}^{4}$, Naqvi SA ${ }^{4}$ \\ ${ }^{1}$ Armed Forces Institute of Pathology Rawalpindi and National University of Medical Sciences (NUMS), Rawalpindi, Pakistan; ${ }^{2}$ Department \\ of Chemical Pathology and Endocrinology, AFIP, Rawalpindi, Pakistan; ${ }^{3}$ Sindh Institute of Urology and Transplantation, Karachi, Pakistan; \\ ${ }^{4}$ Combined Military Hospital, Quetta, Pakistan
}

\begin{abstract}
Objective: To determine association of Sex steroid priming on Growth hormone stimulation test in tertiary care hospital settings Rawalpindi.

Study design: Cross sectional study.

Place and duration of study: Department of Chemical Pathology and Endocrinology, Armed Forces Institute of Pathology (AFIP) Rawalpindi from January 2018 to June 2018.

Methodology: This study was a cross-sectional study conducted after the Institutional Review Board (IRB) approval at AFIP from January 2018 to June 2018.

Data was collected from 149 children of 9-13 year of age reported to endocrinology clinic AFIP, after informed consent. Inclusion criteria included healthy adults with age of 9-13 years with no minor or subclinical illness or endocrinology disorders like hypothyroid, Cushing syndrome or Addison disease. Patients with comorbidity like cancer, tuberculosis and bed ridden patients were excluded from study. Sampling technique was non probability convenience sampling which was done in endocrine clinic of AFIP.

Results: A total of 149 patients were inducted in study who visited Endocrine clinic in AFIP. Mean age of participants was $9.9 \pm 3.9$ year while $96(64.4 \%)$ were male and $52(34.9 \%)$ were female. Total of 149 patients there were 100 $(67.1 \%)$ patients were below $3^{\text {rd }}$ percentile, while $44(29.5 \%)$ were above $3^{\text {rd }}$ percentile but below $50^{\text {th }}$ percentile and 4 $(2.7 \%)$ were at $50^{\text {th }}$ percentile. Independent $T$ test was applied for Priming and response level after growth hormone stimulation test and it gives significant level ( $\mathrm{p}$ value $=0.00$ ) which is considered significant ( $\mathrm{p}$ value $<0.05)$.

Conclusion: This study concluded that priming after sex steroids can affect growth hormone level in pre pubertal children's and it will help in appropriate diagnosis of growth hormone deficiency.
\end{abstract}

Keywords: Growth hormone; Sex steroids; Stimulation test; Short stature

\section{INTRODUCTION}

Growth hormone deficiency is most important cause to evaluate for the assessment of short stature although growth hormone deficiency is not common but the most important case to rule out [1]. Assessment of short stature begins with detailed and careful history and comprehensive detailed physical medical examination including any dysmorphic features, [2] anthropometric measurements like body mass index (BMI), Weight, height, weight for age, height for age, body proportion, midparental height, and pubertal staging [3]. After detailed examination need to rule out other common causes of short stature like hypothyroidism, anemia, and renal disorder [4] and this is followed by initial screening of Insulin like growth factor (IGF-1) and reduced height velocity [5]. Traditionally growth hormone deficiency diagnosis is established by growth hormone response less than cutoff limits of two or more provocative test [6]. Various growth hormone stimulation test is used for this purpose like exercise stimulation test, Levodopa stimulation test, clonidine stimulation test, arginine stimulation test and gold standard used for this purpose is insulin tolerance test which has some side effects like it can cause hypoglycemia, coma and it is contraindicated in patient with heart disease and epilepsy that why it is replaced by glucagon stimulation test [7]. It has been suggested that before growth hormone stimulation test

${ }^{*}$ Correspondence to: Ain QU, Armed Forces Institute of Pathology Rawalpindi and National University of Medical Sciences (NUMS), Rawalpindi, Pakistan, Tel: 03333643355; E-mail: draaneiseera@gmail.com

Received: January 27, 2019; Accepted: March 27, 2019; Published: April 03, 2019

Citation: Ain QU, Noreen, Sheikh WH, Akhtar H, Asif N, Naz S, et al. (2019) Association of Sex Steroid Priming on Growth Hormone Stimulation Test in Tertiary Care Hospital Settings Rawalpindi. Biochem Anal Biochem 8:379. doi: 10.35248/2161-1009.19.8.379.

Copyright: (C) 2019 Ain QU, et al. This is an open-access article distributed under the terms of the Creative Commons Attribution License, which permits unrestricted use, distribution, and reproduction in any medium, provided the original author and source are credited. 
sex steroid priming in prepubertal children of $9-13$ year of age can give more appropriate result as compared to without priming [8]. A survey conducted by European society of pediatric endocrinology in 2001 was suggested that $50.2 \%$ boys and $40.9 \%$ girls showed normal response of growth hormone level after priming [9]. Teenage children with a constitutional delay in growth and puberty (CDGP) often exhibit very low GH secretion following stimulation while still prepubertal or in early puberty, [10] but show a normal increase as puberty progresses. Considering that the rise in sex steroid concentrations, especially estrogen in puberty can increase the growth hormone secretion [11]. If Sex steroids not administrated in pre-pubertal children there is less chances of growth hormone level to rise. While studies supporting that sex steroid priming can improve diagnostic efficiency by reducing false diagnosis of growth hormone deficiency in prepubertal children. This study conducted with the aim to evaluate of sex steroid priming in diagnosis of growth hormone deficiency in prepubertal children.

\section{MATERIAL AND METHODOLOGY}

This study was a cross sectional study conducted after IRB approval at AFIP, from January 2018-September 2018. Data was collected from 149 children of $9-13$ year of age reported to endocrinology clinic AFIP, after informed consent. Inclusion criteria included healthy adults with age of 9.13 years with no minor or subclinical illness or endocrinology disorders like hypothyroid, Cushing syndrome or Addison disease. Patients with comorbidity like cancer, tuberculosis and bed ridden patients were excluded from study. Sampling technique was non probability convenience sampling which was done in endocrine clinic of AFIP. A structured, standardized and pre-tested questionnaire was applied in the pilot study. Independent variables evaluated at the first meeting were socioeconomic and demographic factors (age, gender, and years of schooling and economic class), and presence of morbidities ruled out by biochemical test. Next, the anthropometric data for (weight, height) was measured and plotted on growth chart. Instruments, personnel, and procedure validation were carried out through an internal quality control (QC) program with the calculation of standard deviations (SD) and coefficients of variation (CV). Quality control material was traceable to National institute of standardization (NIST). They were candidates for testing GH secretion because they had height standard deviation score $(\mathrm{Ht}$ SDS) $\leq 2$ standard deviation (SDs), reduced annual growth velocity (growth rate $<5 \mathrm{~cm} /$ year). None had any systemic or endocrine diseases or history of head trauma or irradiation. Children $>9$ years were randomized into two groups: Group 1 received sex steroid priming before performing GHST, and Group 2 did not receive any priming. In boys, intramuscular testosterone depot $25 \mathrm{mg}$ was injected 7-10 days before $\mathrm{GH}$ testing; in girls, oral conjugated estrogen $1.25 \mathrm{mg}$ were prescribed for 3 days before testing. Children $<9$ years did not receive sex steroid priming (Group 3). A standard oral levodopa was performed after overnight fasting at 08:00 am for all the short children. Venous blood was collected at $0,30,60,90$ and 120 min for measuring GH concentrations. Serum IGF-I, Free thyroxine, thyroid stimulating hormone and cortisol concentrations were measured at baseline. Growth hormone and IGF-I were measured by sandwich Chemilumiscence immunometric assays. Intra-assay coefficient of variation $(\mathrm{CVs})$ was 5.6 and $6.9 \%$, respectively, and inter-assay $\mathrm{CV}$ s were 7.9 and $8.2 \%$ respectively.

\section{RESULTS}

A total of 149 patients were inducted in study who visited Endocrine clinic in AFIP. Mean age of participants was $9.9 \pm 3.9$ year while 96 (64.4\%) were male and 52 (34.9\%) were female. Total of 149 patients there were $100(67.1 \%)$ patients were below $3^{\text {rd }}$ percentile, while $44(29.5 \%)$ were above $3^{\text {rd }}$ percentile but below $50^{\text {th }}$ percentile and $4(2.7 \%)$ were at $50^{\text {th }}$ percentile. There were $97 \%$ patients who had basal growth hormone level less than 20 $\mathrm{mg} / \mathrm{dl}$ and provocation test performed in all patients, almost in 61 (40.9\%) patients performed exercise stimulation test, in $69(46.3 \%)$ patients performed levodopa stimulation test and in $15(10.1 \%)$ patients performed insulin tolerance test. Descriptive statistics of all quantitative variables (age, basal Growth hormone level, bone age, height, weight, Hb, TSH level, ATTG, IGF-1, IGF-BP3) were computed (Table 1).

Priming was done in $25(16.8 \%)$ patients before provocation test while in $123(82.6 \%)$ provocation test done without priming. There was 61 (40.9\%) showed adequate response while in $76(51 \%)$ showed inadequate response while there were $11(7.4 \%)$ with partial or equivocal response. Priming response after growth hormone provocation test was shown in Figure 1. Independent $\mathrm{T}$ test was applied for Priming and response level after growth hormone stimulation test and it gives significant level ( $p$ value $=0.00$ ) which is considered significant ( $\mathrm{p}$ value $<0.05$ ). There is strong association among priming and stimulation response before going into growth hormone stimulation test. "Pearson's Chi Square" test applied for association and it also showed significant result ( $\mathrm{p}$ Value<0.05) (Table 2).

\section{DISCUSSION}

There is different school of thoughts for priming with sex steroids before growth hormone stimulation test. The strong argument in favor of priming with sex steroid is that it improves diagnostic

Table 1: Descriptive statistics for quantitative variables (Mean \pm SD).

\begin{tabular}{cccc}
\hline Variables & $\mathbf{n}$ & $\begin{array}{c}\text { Female } \\
\text { Mean } \pm \text { SD }\end{array}$ & $\begin{array}{c}\text { Male } \\
\text { Mean } \pm \text { SD }\end{array}$ \\
\hline Age (Years) & 149 & $9.41 \pm 3.62$ & $10.1 \pm 4.06$ \\
\hline Bone age (Years) & 149 & $7.74 \pm 3.96$ & $7.76 \pm 4.02$ \\
\hline Height (cm) & 149 & $114.21 \pm 18.13$ & $121.62 \pm 20.89$ \\
\hline Weight (kg) & 149 & $20.01 \pm 8.04$ & $24.09 \pm 11.59$ \\
\hline TSH level & 149 & $2.27 \pm 1.25$ & $2.26 \pm 2.48$ \\
\hline Hb & 149 & $11.52 \pm 1.48$ & $13.3 \pm 12.09$ \\
\hline ATTG & 149 & $5.07 \pm 9.01$ & $4.69 \pm 3.73$ \\
\hline IGF-1 & 149 & $21.09 \pm 33.22$ & $24.99 \pm 26.78$ \\
\hline IGFBP3 & 149 & $62.43 \pm 50.32$ & $74.62 \pm 52.31$ \\
\hline Basal GH & 149 & $4.62 \pm 7.15$ & $3.48 \pm 7.25$ \\
\hline GH (Induction) & 149 & $4.92 \pm 13.12$ & $6.17 \pm 13.62$
\end{tabular}

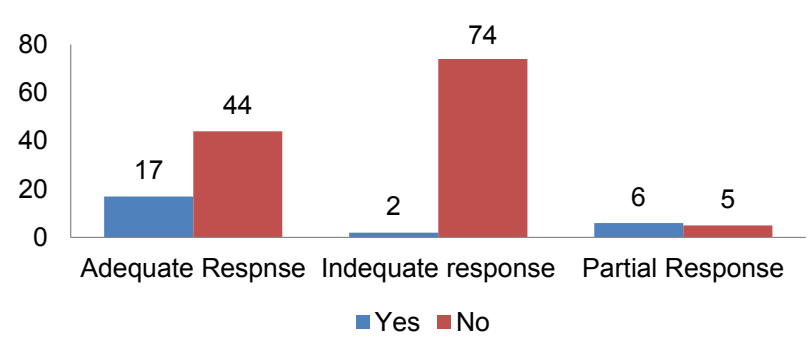

Figure 1: Response after priming in growth hormone stimulation test. 
Table 2: Association (Chi square) of Priming with induction response after Growth hormone stimulation test.

\begin{tabular}{cccc}
\hline Pearson chi square & Value & df & Significane $(<0.05)$ \\
\cline { 2 - 4 } & 80.967 & 1 & 0.000 \\
\hline Likelihood ratio & 64.60 & 1 & 0.000 \\
\hline
\end{tabular}

efficiency with decreased percentage of false positive growth hormone deficiency cases while strong argument which opposed to priming with sex steroid is possibility of under-diagnosis of true cases of growth hormone deficiency as well as controversial use of growth hormone stimulation tests for diagnosis of growth hormone deficiency [11].

In our study, sex steroid priming before different types of growth hormone stimulation was performed in patients of different ages and sex, which showed improved diagnostic efficiency of growth hormone stimulation test in those patients who undergone sex steroid priming before growth hormone stimulation.

It is mentioned in literature that growth hormone response has been increased in group of patients in then estrogen is administered especially in patients with Tanner stage 4 and 5 . They reasoned for that priming reduced the percentage of false positive results in patients with idiopathic short stature.

In one study it is mentioned that priming with sex steroids is not having any effect in improving diagnostic efficiency of growth hormone stimulation test in patients presented with short stature. In this study $16 \%$ of patients were primed with sex steroid while $82 \%$ were not primed and these patients did not mount normal growth hormone response to growth hormone stimulation test. The result of this study is supported by Tillman et al. who determined that growth hormone response to provocative test had not difference in patients who had and had not undergone priming with sex steroids [11].

Murry et al. [7] also have recommended that priming with sex steroids should not be done in every patient presented with short stature and undergoing growth hormone stimulation test. They mentioned that girls with pubertal delay aged $>12$ and boys aged $>13.5$ may be considered for priming with sex steroids before growth hormone stimulation test. Our data supported that priming with sex steroids improved the response of growth hormone to growth hormone stimulation test. Advance research design needed and multicenter approach can further support current study findings.

\section{CONCLUSION}

This study concluded that priming after sex steroids can affect growth hormone level in pre pubertal children's and it will help in appropriate diagnosis of growth hormone deficiency.

\section{CONFLICT OF INTEREST}

No conflict of interest exists.

\section{ACKNOWLEDGEMENT}

All authors would like to extend thanks to participants of research and staff who were involved directly or indirectly.

\section{REFERENCES}

1. MartÍnez AS, Domené HM, Ropelato MG, Jasper HG, Pennisi PA, Escobar ME. Estrogen priming effect on growth hormone $(\mathrm{GH})$ provocative test: a useful tool for the diagnosis of GH deficiency. J Clin Endocrinol Metab. 2000;85:4168-4172.

2. Molitch ME, Clemmons DR, Malozowski S, Merriam GR, Vance ML; Endocrine Society. Evaluation and treatment of adult growth hormone deficiency: An Endocrine Society clinical practice guideline. J Clin Endocrinol Metab. 2011;96:1587-1609.

3. Molitch ME, Clemmons DR, Malozowski S, Merriam GR, Shalet SM, Vance ML, et al. Evaluation and treatment of adult growth hormone deficiency: An Endocrine Society Clinical Practice Guideline. J Clin Endocrinol Metab. 2006;91:1621-1634.

4. Dos Santos C, Essioux L, Teinturier C, Tauber M, Goffin V, Bougnères P. A common polymorphism of the growth hormone receptor is associated with increased responsiveness to growth hormone. Nat Genet. 2004;36:720-724.

5. Gandrud LM, Wilson DM. Is growth hormone stimulation testing in children still appropriate? Growth Horm IGF Res. 2004;14:185-194.

6. Qu XD, Gaw Gonzalo IT, Al Sayed MY, Cohan P, Christenson PD, Swerdloff RS. Influence of body mass index and gender on growth hormone $(\mathrm{GH})$ responses to GH-releasing hormone plus arginine and insulin tolerance tests. J Clin Endocrinol Metab. 2005;90:1563-1569.

7. Murray PG, Dattani MT, Clayton PE. Controversies in the diagnosis and management of growth hormone deficiency in childhood and adolescence. Arch Dis Child. 2016;101: 96-100.

8. Gómez JM, Espadero RM, Escobar-Jiménez F, Hawkins F, Picó A, Herrera-Pombo JL, et al. Growth hormone release after glucagon as a reliable test of growth hormone assessment in adults. Clin Endocrinol. 2002;56:329-334.

9. Meinhardt UJ, Ho KK. Modulation of growth hormone action by sex steroids. Clin Endocrinol. 2006;65:413-422.

10. Palmert MR, Dunkel L. Delayed puberty. New England J Med. 2012;366:443-453.

11. Badaru A, Wilson DM. Alternatives to growth hormone stimulation testing in children. Trends Endocrinol Metab. 2004;15:252-258. 